\title{
Training Center Employees' Perceptions of the Village Animal Health Worker Training Program in Nepal
}

\section{Ramjee Ghimire ${ }^{a, *}$}

${ }^{a}$ Department of Animal Science, Michigan State University, East Lansing, MI 48824, USA

\begin{tabular}{l} 
M A N U S C R I P T I N F O \\
\hline Article history: \\
Received 21 February 2019 \\
Revised 12 March 2020 \\
Accepted 15 April 2020 \\
\hline Keywords: \\
Village animal health worker training \\
Training center \\
Employees' perceptions \\
Nepal
\end{tabular}

\begin{abstract}
A B S T R A C T
Employees are an integral part of training organizations. They play key roles in planning, implementing, and monitoring and evaluation of training programs. However, employees' perceptions of training programs have not been fully studied. Building on professional learning community theory, this study sought to assess training center employees' perceptions of village animal health worker (VAHW) training in Nepal. Twentyseven employees took part in a group-administered survey conducted in June-July 2012. Respondents appreciated trainees' participation in-class discussions, availability of class handouts to trainees, and instructors' facilitation skills. They indicated problems in participant selection, inadequacy of educational materials, and no or limited monitoring and follow-up of training programs. The findings suggest to keep human resources at training centers competent and inclusive, improve the training environments, and pursue programs to sustain VAHW training and associated services.
\end{abstract}

(C) 2020 NAPA. All rights reserved.

\section{Citation:}

Ghimire, R. (2020). Training Center Employees' Perceptions of the Village Animal Health Worker Training Program in Nepal. Global Journal of Agricultural and Allied Sciences, 2(1), 1-10.

\section{Introduction}

Employees represent core human resources in training and educational organizations. They greatly contribute to organizational success (Meijerink, Bondarouk \& Lepak, 2016). They perform multiple tasks and play vital roles in training management; for example, assess training needs, maintain training databases, facilitate training, and monitor the training. They work as liaisons between trainees and instructors and other stakeholders. Training Center employees, specifically support staff, maintain a deeper level of contact and communication with trainees than others. In training and educational institutions, trainees are more comfortable meeting and communicating with support staff than with their instructors (Blatchford et al., 2009). Past studies about training focused mainly on assessing trainees' perspectives of the training (Ghimire \& Suvedi, 2013). Employees' perspectives on the training have drawn only limited attention in research. This study sought to identify training center employees' perceptions of village animal health worker (VAHW) training in Nepal that has been ongoing for over forty years.

Livestock production is an integral part of farming systems and an important source for food, draft power, organic manure, and cash income. The smaller the farm size and farm economy, the higher is the contribution of livestock on livelihoods (Khanh, Ha, Phengsavanh, Horne \& Stür, 2006; Rapsomanikis, 2015). Smallholder farmers in Asia and Africa highly value livestock; however, getting veterinary services for their livestock always remains a challenge. Veterinarians do not work in rural areas as there is not much income, there are no or limited means of transportation, and farmers cannot afford to pay veterinarian fees (Catley et al., 2004; Umali, Feder \& Hann, 1994). Grassroot animal health workers who are called village animal health workers (VAHW) in Nepal, barefoot animal doctors in China, and community-based animal health workers (CAHW) in Africa are the veterinary service providers serving such farmers (Catley et al., 2004; Mockshell, Ilukor \& Birner, 2014; Stoufer, Ojha \& Parajuli, 2002).

The history of village animal health services dates back to the early 1980s when privatization of animal health services started (Young, Stoufer, Ojha \& Dijkema, 1994). According to Riviere-Cinnamond (2005), to offset the failure of government veterinary services in serving farmers in developing countries, the World Bank introduced the village animal health worker training program. The premise of privatization of services is based on the fact that private providers are efficient in serving their clients because their businesses depend on their clients' evaluation and willingness to pay for their services. Private providers strive their best to serve their clients and remain accountable for their service; therefore, clients tend to seek services from private providers (Umali et al., 1994).

The concept of the VAHW services is to train select rural people on basic animal health care and mobilize them to provide animal health services in their communities. The VAHW training is a one-month long training wherein participants learn about basic animal health care. Trainees are supposed to receive adequate hands-on exposure so that after the training they are competent and confident to provide farmers with animal

*Corresponding author. E-mail address: ghimirer@msu.edu 
health and advisory services. The VAHWs manage their livelihoods from the fee farmers pay to them; therefore, the VAHW service is also considered a form of self-employment in rural areas where other employment opportunities are limited.

The VAHWs work on livestock disease prevention and control. They should be knowledgeable about animal body systems, including physical parameters (e.g., temperature, pulse rate, respiration rate and body weight) and common veterinary drugs and their application procedures. Restraining and examination of animals; sterilization of the veterinary equipment; drug administration; castration of male animals; fecal examination for intestinal worms and flukes; measuring animal body weight; and collecting samples (e.g., blood, urine, etc.) and sending them to laboratory for investigation and analysis are some routine procedures they perform.

In Nepal, the Department of Livestock Services (DLS), Council for Technical Education and Vocational Training (CTEVT), and a few nongovernmental organizations (NGOs) offer the VAHW training, but DLS has the largest share. United Mission to Nepal has been the most visible NGO in VAHW training in Nepal (Stoufer, Ojha \& Parajuli, 2002). According to the DLS annual report (2011), out of about 15,000 trainees who received training, only $26 \%$ were working as VAHWs.

A few studies discussed roles of VAHWs. Allport, Mosha, Bahari, Swai \& Catley (2005) reported Community Animal Health Workers (CAHW) carrying out disease surveillance in Africa. Calba et al. (2014) reported that Cambodia trained and mobilized VAHWs in Avian Influenza (AI) surveillance after AI became endemic in the country in 2006. VAHWs also serve as mentors to farmers and other community members and help local people financially, for example, with credit. Citing examples from Africa, Mugunieri, Irungu \& Omiti (2004) report that services of CAHW have not only benefitted the community they belong to, but also surrounding communities, resulting in positive externalities.

In Nepal, the livestock subsector has a significant share in agricultural gross domestic product. Livestock production is a lifeline for many smallholder farmers. Nepal has one of the highest veterinarian: livestock $(1: 47,000)$ (NVC, 2019) and human: livestock (1:3.6) ratios in Asia (IRIN, 2013). During his 15 -year career as a government veterinarian in Nepal, the author has met many farmers who shared difficulty getting timely and quality animal health services. They recalled VAHWs lacking knowledge and skills to carry out services, and the government's lack of attention towards improving VAHW services. Catley et al. (2004) also discussed potential conflict in scopes of VAHWs and veterinary professionals' roles and responsibilities in African small-holder integrated farming systems. Many of these issues and controversies would not exist today if VAHW trainings were planned and executed effectively.

In Nepal, Regional Livestock Services Training Centers (RLSTC) play a key role in managing VAHW training. The District Livestock Service Offices, Non-governmental Organizations, Village Development Committees, and District Development Committees wanting to train their constituents as VAHWs sponsor the training and request the RLSTCs to run the training. Oftentimes, the RLSTCs themselves initiate the training planning process. Once a plan is set, the RLSTCs finalize the training schedule and inform respective sponsors to send participants. Except for two basic criteria for trainee selection (i.e., age and education), participant selection criteria and process may vary depending on training sponsors.

The RLSTC employees play vital role in conducting VAHW training effectively. Upon arrival, they receive participants, and inform and guide participants about provision of lodging, food, and training logistics. Employees are required to provide an appropriate learning place and proper educational materials to participants. RLSTC employees with a bachelor's degree or above education can also serve as training resource persons (RLSTCs, 2011). Employees also develop and organize training materials, for example, equipment, veterinary medicines, and chemicals for practical classes. They find suitable resource persons external to the RLSTCs, if needed. Concurrently, employees serve as proxy counselors for trainees during the training period.

Competition and demand for training resources are high. Stakeholders demand training programs that are effective and can provide tangible outcomes. A few studies have examined VAHW training and VAHW services. Ghimire \& Suvedi (2013) assessed alumni perceptions of VAHW training, and they found training to be theory-laden. Neopane (2007) and Kshatri (2011) evaluated effectiveness of the VAHW training, but their studies lacked methodological clarity in this author's view. Catley et al. (2004) studied the effectiveness of the services of CAHW in Africa and they found CAHWs to be contributing to animal health services delivery.

Limited information is available on the employees' roles in educational and training institutions (Pitman, 2000; Olivier, 2006). Employees' demographics, their experiences of working in training institutions, and their experience in facilitating farmer level training have rarely been studied. Having worked as training organizers, training facilitators and support staffs, employees (hereinafter referred to and synonymously used as 'staff') are in a better position to assess the effectiveness of the training and contribute to its continuous improvement.

This study sought to examine the training center employees' perceptions of the VAHW training and the ways to help improve VAHW training in Nepal. The specific objectives were to: (1) determine the sociodemographic characteristics of the training center employees; (2) assess training center employees' perceptions of VAHW training; and (3) solicit the employees' input about problems hindering VAHW training and VAHW services. The findings of the study could help improve VAHW and other similar farmers training programs, and bolster learning outcomes among trainees.

\subsection{Conceptual Framework}

For learning to be effective, learning environments must be learner-friendly and safe (Vella, 2002). Employees at the training institutions play key roles in creating conducive learning environments for learners. Recalling professional learning community theory posited by Bohn $(1985,1986)$, Mitchell \& Sackney (2007) explained employees' positions and roles in relation to instructors within training and educational institutions. People working in the education and training institutions maintain reciprocity, mutuality, and cordial relationships with trainees. Employees are an integral part of the learning community.

In education and training institutions, an instructor alone cannot achieve the stipulated goals of the institutions, so support and cooperation from the other staff (or employees) are essential (Banta \& Kuh, 1998). When trainees are new to the training programs and to the educational venues, employees have to be even more proactive and responsive to help trainees with guidance in adapting to the new environment. According to Pitman (2000), employees not only play the role of service providers, but also of mentors. Employees perceive trainees as their internal customers. How employees communicate with trainees, how they behave with trainees, how they help trainees, and how they serve trainees in and outside the classrooms, in dorms, in laboratories, in training halls, and during site tours and visits greatly impact trainees' learning outcomes (Santos \& Stuart, 2003). Employees' positive and proactive roles in training centers are catalytic in creating safe and trainee-friendly learning environments. Emphasizing 
employees' proximity to trainees and their contribution in training and education, Blatchford et al. (2009) noted that trainees are more likely to passively "attend" to instructors, while they engage in far more active and sustained interaction with other employees. It can thus be said that training center employees are more effective in explaining and articulating how the training programs have been and how those programs could be improved. Employees' input would be useful to study training dynamics.

As can be articulated from the above discussion, the training cycle begins with pre-training preparation, and continues with training and posttraining stages. To better understand training programs and the underlying issues, training related studies should consider examining the pre-, during, and post-training activities (Easterby-Smith, 1986 as cited in Santos \& Stuart, 2003). Building on these thoughts, this study collected some pre-, during, and post-training related information from employees at five RLSTCs.

\section{Study Methods}

The study had 36 employees, both technical and administrative, working in five Regional Livestock Services Training Centers (RLSTCs), as its study population. The five RLSTCs included Eastern, Central, Western, MidWestern, and Far Western regions of Nepal. The researcher-designed survey was used to collect data. The survey consisted of two sections. The first section contained 17 statements pertaining to different aspects of VAHW training, ranging from participant selection to training follow-up. The respondents had to rate these statements on a scale from 1 to 5 , with 1 equated to "strongly disagree," 2 as "disagree," 3 as "undecided," 4 as "agree," and 5 as "strongly agree." The survey included a few demographic questions seeking information about respondent's total years of service at training center(s), as well as in public service, their education level, and whether they attended the "training for trainer." There were two openended questions about the problems or limitations of the VAHW training and suggestions for its improvement. Five graduate students attending a program evaluation course in the Department of Community Sustainability (CSUS) at Michigan State University (MSU) reviewed the survey and provided feedback. In addition, input from extension educators at MSU CSUS and extension professionals at DLS Nepal was sought to ensure the face and content validity of the survey. The survey was translated into Nepali language. This study had Michigan State University's Institutional Review Board approval.

The investigator met staff in person at their respective training centers, and briefed them about the objectives of the study. Staff were informed that their participation in the study was voluntary. Group-administered surveys are deemed appropriate for people who live or work closely together within their unit (Bourque \& Fielder, 2003). Therefore, the surveys of the training center staff were administered in a group setting. A few staff who could not join the group filled out the survey at their place of convenience. For those who could not be reached, the investigator left the survey with a postagepaid stamped envelope to the training center chief and asked him/her to get the survey filled out by the staff and to return the survey to the investigator's post box. No such survey was received. One staff member from the central region opted out of the survey, citing his recent posting and him being unaware of VAHW training. The researcher maintained the confidentiality of the data and the anonymity of the participants' identities.

Data were transcribed into the English language and were then analyzed using SPSS version 20. Qualitative data were collated and coded to identify key themes. The reliability coefficient of the 17 statements, calculated posthoc, was found to be 0.91 , indicating that statements consistently and uniformly measured the trainees' perceptions.

Sample size being small ( $\mathrm{n}=27)$, non-parametric tests, Mann Whitney test and Kruskal-Wallis were used for examining the differences in dependent variables. Likert scale statements were also examined employing median and interquartile range.

Small sample size is one of the limitations of this study, which readers should consider while generalizing the results. The data were collected in 2012; therefore, information presented in the paper is somewhat dated. Nevertheless, given that there has been no study examining staff perceptions of VAHW training programs in Nepal, the findings are original and may still be relevant to agricultural extension education and the training sector.

\section{Results}

\subsection{Demographics}

The majority ( $70 \%$ ) of the respondents have been in public service for more than 16 years, with on average service period of 21 years. Staff from the central region had the lowest, and the far west region had the highest average total service period of 16 years and 25 years, respectively. However, their services at training centers had been relatively short. Twothirds of them had been in training centers for four years or less. More than half $(59 \%)$ of the respondents reported that they had attended "training of trainer (TOT)". About half ( $\mathrm{n}=13)$ of the staff had a bachelor's degree or equivalent education. Regional Livestock Services Training Center annual reports showed that of 36 staff working at five training centers, $92 \%(n=33)$ were males and only $8 \%(n=3)$ were females (RLSTCs, 2011).

\subsection{Staff Perceptions of Training}

Table 1 presents descriptive statistics of respondents' rating on various aspects of VAHW training. A large percentage (92.5\%) of the respondents agreed or strongly agreed that there was no difficulty in finding appropriate resource persons for the training, and the participants actively took part in in-class discussion. The three statements with higher than average ratings were that class handouts were provided on time, participants liked the methods of instruction, and the criteria for participant selection were practical. Statements receiving the lowest and/or neutral ratings included participant were satisfied with the daily allowance they received and participant selection being free and fair. Median range of four for all but one statements supports that respondents answered all except the statement on daily allowance affirmatively.

\subsection{Problems in VAHW Training and Suggestions for Improvement}

When asked to share the problems in the VAHW training, participants listed 51 problems, with an average of two problems per participant (Table 4). Inappropriate participant selection was the most raised issue $(n=12)$, followed by an inadequacy of training materials $(n=6)$ and the dorms not being livable for trainees to reside in $(n=5)$. The problems mentioned ranged from pre-, during, and post-training issues, as well as those related to trainees, trainers, and training management, and policy issues. Participant selection was the major pre-training issue, while dorms not being livable, and inadequacy of educational materials were the most listed 
during-training issues. The post-training issue that respondents felt most problematic about was the lack of programs for transfer of knowledge in the training plan. While all four groups indicated a problem in participant selection and training needs assessment not being adequately done, those with a bachelors' degree raised questions about the legality of the VAHW services, and not much being done in quality control of training.

Twenty-seven respondents offered 57 suggestions to improve the VAHW training (Table 5). As with problems, improvement in the participant selection process dominated the suggestions $(n=10)$. The need for skillful or qualified instructors, and urgency for refresher training, and monitoring and follow-up of the training were the second most pressing suggestions $(\mathrm{n}=5)$. Those respondents with TOT focused on institutional development and strengthening of the VAHW training, including, the need for refresher training, revision of curriculum, allowing only the capable institutions to run the training, and urgency for regular monitoring and evaluation of the training. Those with no TOT emphasized free and fair selection.

Independent sample Mann-Whitney-test results showed that respondents with $(\mathrm{n}=16)$ and without $(\mathrm{n}=11)$ training of trainers (TOT) did not differ in their perceptions of the statements about training except for the statement that training center conducted follow-up studies of the training, which those who received TOT rated more positively than with non-TOT (Table 2).

Further, Kruskal-Wallis test results showed that respondents perceived similarly of different training statements irrespective of their educational backgrounds (Table 3 ).

Table 1. Perception ratings of the statements related to VAHW training.

\begin{tabular}{|c|c|c|c|c|c|}
\hline \multirow[t]{2}{*}{ Statements } & \multicolumn{2}{|l|}{$\begin{array}{l}\text { Strongly } \\
\text { disagree or } \\
\text { disagree }\end{array}$} & \multirow{2}{*}{$\begin{array}{l}\text { Strongly } \\
\text { agree or } \\
\text { agree } \\
\%\end{array}$} & \multirow[t]{2}{*}{ Median } & \multirow[t]{2}{*}{$\begin{array}{l}\text { Inter } \\
\text { Quartile (IQ) } \\
\text { Range }\end{array}$} \\
\hline & $\%$ & $\%$ & & & \\
\hline Need assessment was done before proposing the training. & 7.4 & 22.2 & 70.3 & 4 & 2 \\
\hline Participant selection was free and fair. & 15.4 & 38.5 & 46.1 & 4 & 1 \\
\hline Criteria for participant selection were practical. & - & 7.4 & 92.6 & 4 & 1 \\
\hline Training halls were comfortable. & 7.4 & 14.8 & 77.7 & 4 & 2 \\
\hline Hostels were comfortable for trainees to live in during training. & 7.4 & 22.2 & 70.3 & 4 & 1 \\
\hline Participants actively participated in discussion. & - & - & 100 & 4 & 1 \\
\hline Adequate animals were available for participants to practice on. & 3.8 & 11.5 & 84.6 & 4 & 1 \\
\hline There were no difficulties in finding appropriate instructors. & 3.7 & 3.7 & 92.5 & 4 & 1 \\
\hline There were adequate training materials for the training. & 3.7 & 18.5 & 77.8 & 4 & 1 \\
\hline Participants liked the methods of instruction. & 4 & 4.0 & 92.0 & 4 & 1 \\
\hline Class handouts were provided on time. & 3.7 & 3.7 & 92.6 & 4 & 1 \\
\hline Participants understood the subject well. & - & 18.5 & 81.5 & 4 & 1 \\
\hline Instructors were knowledgeable about the course materials. & 11.1 & 3.7 & 85.2 & 4 & 1 \\
\hline Participants were satisfied with the daily allowance they received. & 20 & 52.0 & 28.0 & 3 & 0 \\
\hline Training duration was adequate. & 14.8 & 14.8 & 70.3 & 4 & 2 \\
\hline Instructors were satisfied with the remuneration they received. & 11.1 & 25.9 & 62.9 & 4 & 1 \\
\hline Training centers follow-up of the training. & 11.5 & 11.5 & 76.9 & 4 & 1 \\
\hline
\end{tabular}


Table 2. Differences in the perceptions between those who received and did not receive TOT training.

\begin{tabular}{|c|c|c|c|c|c|c|c|c|}
\hline Statements & Received TOT & $\mathbf{N}$ & Median & IQ Range & $\begin{array}{l}\text { Mann- } \\
\text { Whitney U }\end{array}$ & Wilcoxon W & $\mathbf{Z}$ & p- value \\
\hline \multirow{2}{*}{$\begin{array}{l}\text { Need assessment was done before proposing the } \\
\text { training. }\end{array}$} & Yes & 16 & 4 & 2 & \multirow{2}{*}{81.500} & \multirow{2}{*}{147.500} & \multirow{2}{*}{-0.339} & \multirow{2}{*}{0.735} \\
\hline & No & 11 & 4 & 1 & & & & \\
\hline \multirow[b]{2}{*}{ Participants selection was free and fair. } & Yes & 16 & 3 & 2 & \multirow[b]{2}{*}{73.500} & \multirow[b]{2}{*}{128.500} & \multirow[b]{2}{*}{-0.361} & \multirow[b]{2}{*}{0.718} \\
\hline & No & 10 & 3.5 & 2 & & & & \\
\hline \multirow{2}{*}{ Qualifications for participants selection were practical. } & Yes & 16 & 4 & 2 & \multirow[b]{2}{*}{61.000} & \multirow[b]{2}{*}{127.000} & \multirow[b]{2}{*}{-1.565} & \multirow[b]{2}{*}{0.118} \\
\hline & No & 11 & 4 & 0 & & & & \\
\hline \multirow{2}{*}{ Training halls were comfortable. } & Yes & 16 & 4 & 2 & \multirow[b]{2}{*}{70.500} & \multirow{2}{*}{206.500} & \multirow[b]{2}{*}{-0.924} & \multirow{2}{*}{0.355} \\
\hline & No & 11 & 4 & 1 & & & & \\
\hline \multirow{2}{*}{$\begin{array}{l}\text { Hostels were comfortable for trainees to live in during } \\
\text { training. }\end{array}$} & Yes & 16 & 4 & 2 & \multirow{2}{*}{58.000} & \multirow{2}{*}{194.000} & \multirow{2}{*}{-1.590} & \multirow{2}{*}{0.112} \\
\hline & No & 11 & 4 & 1 & & & & \\
\hline \multirow{2}{*}{ Participants actively participated in discussion. } & Yes & 16 & 4.5 & 1 & \multirow{2}{*}{68.000} & 124000 & 1,0 & 0207 \\
\hline & No & 11 & 4 & 1 & & & - & 0.241 \\
\hline Adequate animals were available for participants to & Yes & 16 & 4 & 1 & 62500 & 117500 & 1002 & 0307 \\
\hline practice on. & No & 10 & 4 & 0 & 02.000 & 111.000 & -1.022 & 0.001 \\
\hline There were no difficulties in finding appropriate & Yes & 16 & 4 & 1 & 86000 & 222000 & 0110 & 0012 \\
\hline instructors. & No & 11 & 4 & 1 & 00.000 & 222.000 & -0.110 & 0.912 \\
\hline & Yes & 16 & 4 & 1 & & & & \\
\hline I here were adequate trainıng materials for the trainıng. & No & 11 & 4 & 1 & 58.500 & 124.500 & -1.615 & 0.106 \\
\hline & Yes & 15 & 4 & 1 & & & & \\
\hline Participants liked the metnods on instruction. & No & 10 & 4 & 0.25 & 39.000 & 114.000 & -1.023 & 0.500 \\
\hline & Yes & 16 & 4 & 1 & & & & \\
\hline Class handouts were provided in time. & No & 11 & 4 & 1 & 81.000 & 147.000 & -0.388 & 0.698 \\
\hline Doticin nto ndorto the & Yes & 16 & 4 & 0.75 & & & & \\
\hline Participants understood tne suoject wen. & No & 11 & 4 & 1 & 59.000 & 125.000 & -1.116 & 0.086 \\
\hline Instructors were knowledgeable about the course & Yes & 16 & 4 & 1 & 84500 & 150500 & 0106 & 0844 \\
\hline materials. & No & 11 & 4 & 1 & 04.200 & 150.000 & -0.190 & 0.044 \\
\hline Participants were satisfied with the daily allowance & Yes & 15 & 3 & 1 & 68000 & 123000 & $=421$ & 0674 \\
\hline they received. & No & 10 & 3 & 2 & 00.000 & 125.000 & -0.421 & $0.0 / 4$ \\
\hline Training duration was anpropriat & Yes & 16 & 4 & 1.75 & 84000 & 00 & & \\
\hline maming auration was appropriate. & No & 11 & 4 & 2 & 84.000 & 220.000 & -0.209 & 0.834 \\
\hline Instructors were satisfied with the remuneration they & Yes & 16 & 4 & 1 & 77000 & $21200 \Omega$ & 571 & 560 \\
\hline got. & No & 11 & 4 & 2 & 11.000 & 215.000 & $-0.5 / 1$ & 0.500 \\
\hline Training center conducted follow-up studies of the & Yes & 16 & 4 & 1 & 43.500 & 08500 & 2151 & 0031 \\
\hline training. & No & 10 & 4 & 1.25 & 43.200 & 90.500 & -2.151 & 0.001 \\
\hline
\end{tabular}


Table 3. Kruskal-Wallis test results showing differences in perceptions among respondents with four education levels.

\begin{tabular}{|c|c|c|c|c|c|c|}
\hline Statements & Level of education & $\mathbf{N}$ & Median & Kruskal-Wallis $\mathbf{H}$ & $d f$ & $p$-value \\
\hline \multirow{4}{*}{ Need assessment was done before proposing the training. } & Tenth grade or equivalent & 4 & \multirow{4}{*}{4} & \multirow{4}{*}{6.643} & \multirow{4}{*}{3} & \multirow{4}{*}{0.084} \\
\hline & Twelfth grade or equivalent & 5 & & & & \\
\hline & Bachelor's or equivalent & 13 & & & & \\
\hline & Master's or above & 5 & & & & \\
\hline \multirow{4}{*}{ Participants selection was free and fair. } & Tenth grade or equivalent & 3 & \multirow{4}{*}{3} & \multirow{4}{*}{3.132} & \multirow{4}{*}{3} & \multirow{4}{*}{0.372} \\
\hline & Twelfth grade or equivalent & 5 & & & & \\
\hline & Bachelor's or equivalent & 13 & & & & \\
\hline & Master's or above & 5 & & & & \\
\hline \multirow{4}{*}{ Qualifications for participants selection were practical. } & Tenth grade or equivalent & 4 & \multirow{4}{*}{4} & \multirow{4}{*}{2.953} & \multirow{4}{*}{3} & \multirow{4}{*}{0.399} \\
\hline & Twelfth grade or equivalent & 5 & & & & \\
\hline & Bachelor's or equivalent & 13 & & & & \\
\hline & Master's or above & 5 & & & & \\
\hline \multirow{4}{*}{ Training halls were comfortable. } & Tenth grade or equivalent & 4 & \multirow{4}{*}{4} & \multirow{4}{*}{5.278} & \multirow{4}{*}{3} & \multirow{4}{*}{0.153} \\
\hline & Twelfth grade or equivalent & 5 & & & & \\
\hline & Bachelor's or equivalent & 13 & & & & \\
\hline & Master's or above & 5 & & & & \\
\hline \multirow{4}{*}{ Hostels/dorms were comfortable for trainees to live in during training. } & Tenth grade or equivalent & 4 & \multirow{4}{*}{4} & \multirow{4}{*}{6.590} & & \\
\hline & Twelfth grade or equivalent & 5 & & & & \\
\hline & Bachelor's or equivalent & 13 & & & 3 & 0.080 \\
\hline & Master's or above & 5 & & & & \\
\hline & Tenth grade or equivalent & 4 & & & & \\
\hline & Twelfth grade or equivalent & 5 & & & & \\
\hline Participants actively participated in discussion. & Bachelor's or equivalent & 13 & 4 & 1.163 & 3 & 0.762 \\
\hline & Master's or above & 5 & & & & \\
\hline & Tenth grade or equivalent & 4 & & & & \\
\hline 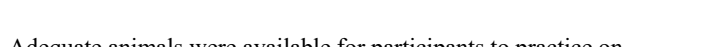 & Twelfth grade or equivalent & 5 & 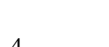 & 1628 & 3 & 0651 \\
\hline 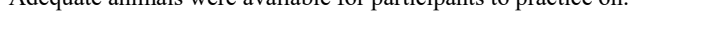 & Bachelor's or equivalent & 13 & & & & \\
\hline & Master's or above & 4 & & & & \\
\hline & Tenth grade or equivalent & 4 & & & & \\
\hline There were no difficulties in finding annronriate instructors & Twelfth grade or equivalent & 5 & 4 & 0904 & 3 & 0825 \\
\hline & Bachelor's or equivalent & 13 & & & & \\
\hline & Master's or above & 5 & & & & \\
\hline & Tenth grade or equivalent & 4 & & & & \\
\hline 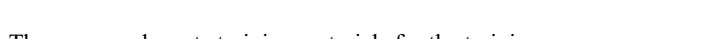 & Twelfth grade or equivalent & 5 & & & & \\
\hline inere were adequate trammg materias sor tne trammg. & Bachelor's or equivalent & 13 & 4 & $2.5 / 0$ & 3 & 0.403 \\
\hline & Master's or above & 5 & & & & \\
\hline & Tenth grade or equivalent & 4 & & & & \\
\hline & Twelfth grade or equivalent & 5 & & & & \\
\hline Participants liked the methods of instruction. & Bachelor's or equivalent & 11 & 4 & 4.987 & 3 & 0.173 \\
\hline & Master's or above & 5 & & & & \\
\hline & Tenth grade or equivalent & 4 & & & & \\
\hline $\mathrm{Cl}$ & Twelfth grade or equivalent & 5 & a & (2) & ? & $707+20$ \\
\hline 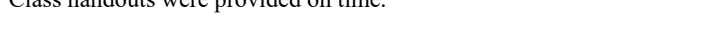 & Bachelor's or equivalent & 13 & 4 & 2.902 & J & 0.591 \\
\hline & Master's or above & 5 & & & & \\
\hline
\end{tabular}




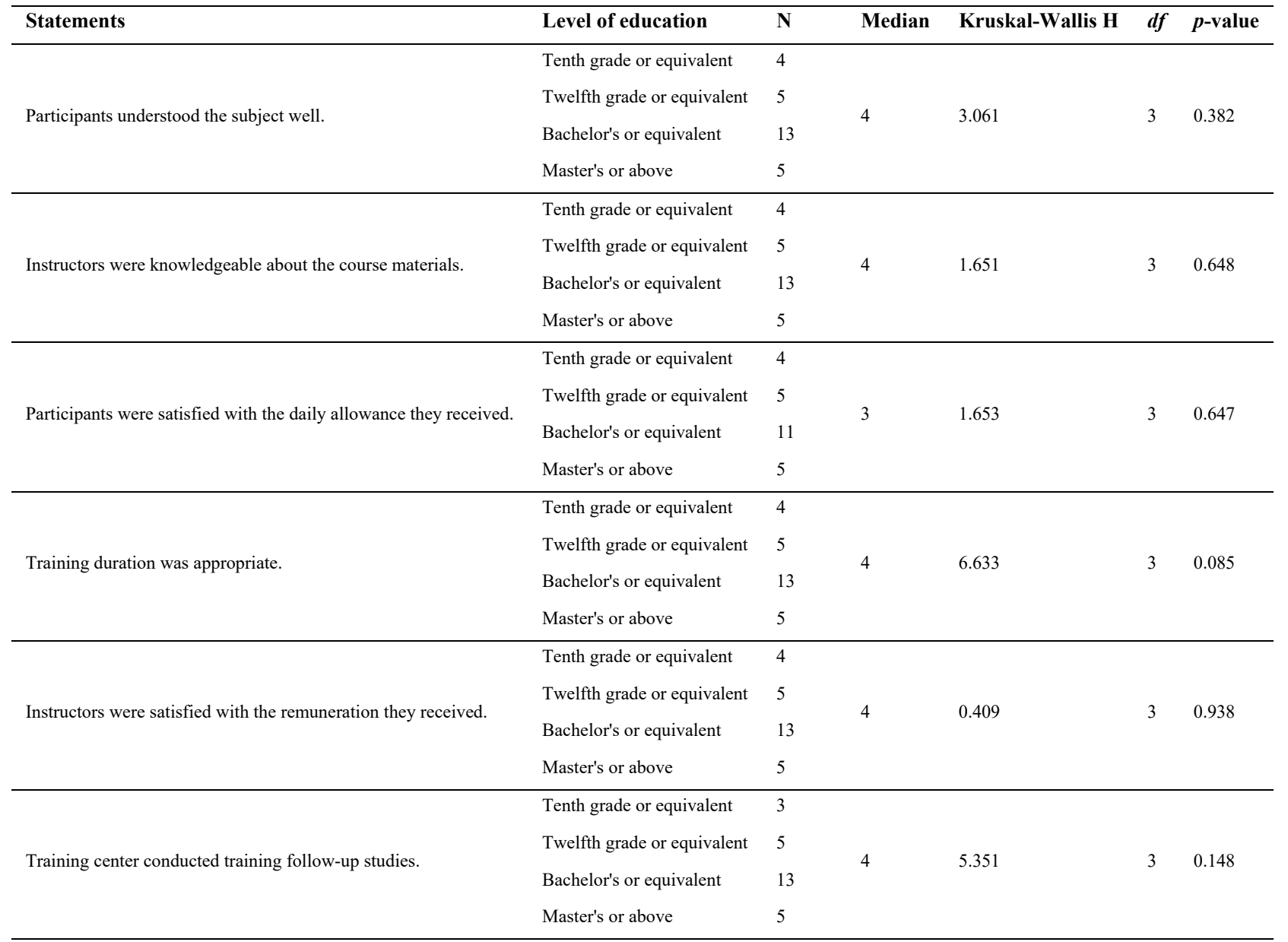

Table 4. Problems of VAHW training as perceived by staff (respondents $=27$, responses $=51$ ).

\begin{tabular}{|c|c|c|c|c|c|}
\hline Problems & $n$ & $\%$ & Problems & $n$ & $\%$ \\
\hline $\begin{array}{l}\text { Inappropriate } \\
\text { participant selection }\end{array}$ & 12 & 23.5 & $\begin{array}{l}\text { Other: Inadequate per } \\
\text { diem, no opportunity } \\
\text { for a refresher training, }\end{array}$ & 14 & 28.0 \\
\hline $\begin{array}{l}\text { Lack of training } \\
\text { materials }\end{array}$ & 6 & 11.8 & $\begin{array}{l}\text { no or minimal hands- } \\
\text { on sessions, lack of }\end{array}$ & & \\
\hline $\begin{array}{l}\text { Dorms were not } \\
\text { comfortable to live in }\end{array}$ & 5 & 9.8 & $\begin{array}{l}\text { equipment with } \\
\text { VAHWs, difficulty in } \\
\text { mobility, no proper }\end{array}$ & & \\
\hline $\begin{array}{l}\text { Less competent } \\
\text { instructors }\end{array}$ & 3 & 5.9 & $\begin{array}{l}\text { planning done for } \\
\text { training, no session on }\end{array}$ & & \\
\hline Shorter training period & 3 & 5.9 & forage production, no & & \\
\hline $\begin{array}{l}\text { No monitoring and } \\
\text { follow-up }\end{array}$ & 2 & 3.9 & $\begin{array}{l}\text { program for transfer of } \\
\text { training, no regulation } \\
\text { to legalize VAHW }\end{array}$ & & \\
\hline Budgetary constraints & 2 & 3.9 & services, VAHWs have & & \\
\hline $\begin{array}{l}\text { Training is sought to } \\
\text { get VAHW license } \\
\text { only }\end{array}$ & 2 & 6.9 & $\begin{array}{l}\text { to cover a wide } \\
\text { geographical area }\end{array}$ & & \\
\hline $\begin{array}{l}\text { Lack of practical } \\
\text { animals }\end{array}$ & 2 & 3.9 & & & \\
\hline
\end{tabular}

Note: Some respondents gave more than one suggestion.

\section{Discussion}

Even though the staff at training centers possessed extensive experience in public service, their experience in training centers appeared to be relatively short. This could be due to training staff being frequently transferred to new positions vis-à-vis they did not prefer to work in training centers for a long time. Frequent staff turnover is a problem in many institutions. Organizing and/or conducting training is an art, which training center staff must master. Frequent staff turnover at RLSTC do not allow this to happen. Not having staff trained on training of trainer (TOT) is another pressing issue facing VAHW training. TOT is effective in imparting pedagogical knowledge and skills including communication and teaching methodologies to training participants (Ojango et al., 2011); therefore, trainers should take TOTs.

RLSTC employees were dominantly male. In Nepal, women perform $70 \%$ of the farm work, and they need training the most (FAO, 2019). On the contrary, very few women get opportunity for training. Further, women attending training were found to be discriminated against in many ways, and training materials and logistics, including dorms, classrooms, and practical classes were unfriendly to female trainees (unpublished data).

Respondents' perceptions of most aspects of VAHW training remained positive. Participants' active participation in class discussion is an indicator of training being effective. This could be because trainees liked the training topics and teaching of instructors. Strong agreement by employees that they 
were able to find appropriate instructors to run training supports these points.

Table 5. Staff's suggestions to improve VAHW training (respondents $=27$, responses $=57$ )

\begin{tabular}{|c|c|c|c|c|c|}
\hline Suggestions & $n$ & $\%$ & Suggestions & $n$ & $\%$ \\
\hline $\begin{array}{l}\text { Employ an appropriate } \\
\text { participant selection } \\
\text { process }\end{array}$ & 10 & 17.5 & $\begin{array}{l}\text { Make the training a } \\
\text { little longer }\end{array}$ & 2 & 3.5 \\
\hline $\begin{array}{l}\text { Mobilize skillful } \\
\text { instructors/resource } \\
\text { persons }\end{array}$ & 5 & 8.8 & $\begin{array}{l}\text { Revise/update the } \\
\text { training syllabus }\end{array}$ & 2 & 3.5 \\
\hline $\begin{array}{l}\text { Provide refresher } \\
\text { training }\end{array}$ & 5 & 8.8 & $\begin{array}{l}\text { Make sure that } \\
\text { learning/training } \\
\text { environment is safe } \\
\text { and learner-friendly }\end{array}$ & 2 & 3.5 \\
\hline $\begin{array}{l}\text { Regularly monitor and } \\
\text { follow-up }\end{array}$ & 5 & 8.8 & $\begin{array}{l}\text { Other: promote } \\
\text { collaboration in }\end{array}$ & 7 & 12.6 \\
\hline $\begin{array}{l}\text { Provide required } \\
\text { educational materials }\end{array}$ & 4 & 7.0 & $\begin{array}{l}\text { training, follow } \\
\text { "learning by doing" } \\
\text { approach make sure }\end{array}$ & & \\
\hline $\begin{array}{l}\text { Government should } \\
\text { bear the trainees' cost }\end{array}$ & 4 & 7.0 & $\begin{array}{l}\text { that training is } \\
\text { provided by qualified }\end{array}$ & & \\
\hline $\begin{array}{l}\text { Conduct training needs } \\
\text { assessment prior to } \\
\text { training }\end{array}$ & 3 & 5.3 & $\begin{array}{l}\text { institutions, ensure } \\
\text { power supply at } \\
\text { training center, }\end{array}$ & & \\
\hline $\begin{array}{l}\text { Formulate and enact } \\
\text { laws and bylaws to } \\
\text { legalize VAHW } \\
\text { services }\end{array}$ & 3 & 5.3 & $\begin{array}{l}\text { provide per diem } \\
\text { that is adequate } \\
\text { enough to support } \\
\text { trainee's stay during } \\
\text { training, reward the }\end{array}$ & & \\
\hline $\begin{array}{l}\text { Offer more practical } \\
\text { and hands-on } \\
\text { opportunities }\end{array}$ & 3 & 5.3 & $\begin{array}{l}\text { best performers, } \\
\text { make sure that there } \\
\text { no participants }\end{array}$ & & \\
\hline $\begin{array}{l}\text { Ensure that } \\
\text { materials/logistics for } \\
\text { practical are adequate }\end{array}$ & 2 & 3.5 & $\begin{array}{l}\text { attending the same } \\
\text { training twice }\end{array}$ & & \\
\hline
\end{tabular}

Note: Some respondents gave more than one suggestion.

Training outcomes and effectiveness largely depend on the qualification and motivation of participants. Training would be effective if those who need training and who are motivated for and determined to receive training participate in the program (Lim \& Johnson, 2002). Despite having participant selection criteria in place, which participants mentioned as being practical, not being able to implement these criteria in their entirety was a matter of concern. Both the qualitative and quantitative data revealed that not having a proper participant selection process in place is as an issue. This fact was clearly substantiated by respondents indicating unfair participant selection process.

Assessing training needs is a prerequisite for any training program (Das \& Mishra, 2013; Cho \& Boland, 2004). Participant selection should be based on local needs. Community members are well-placed to suggest human resources needed in their communities and judge the qualities of potential workers; therefore, they should be a part of the VAHW training participant selection process (Catley et al., 2004). The following verbatim responses from respondents echoed these concerns. "VAHW training should be provided to the people of those areas where veterinary service is not available..." "Some participants are found not to be working after training. Trainees who get offers for higher education and other opportunities are leaving this profession." Resources would have been better utilized, had those who were not sure about pursuing a VAHW profession after the training opted out on time to allow a more committed trainee to participate in the program.

Employees suggested flexibility in selecting trainees from rural areas where access to veterinary services is limited. The current VAHW training program guidelines mention training participants being required to have at least ten years of education (DLS, 2011; RLSTCs, 2011). Respondents felt that rural and remote areas where the need for VAHW services is high, may not have participants with ten years of education. Two respondents wrote:

\section{"It is still difficult to find trainees in remote areas who are SLC (School Leaving Certificate) appeared, so often those studying [attending schools/colleges] are selected." \\ "SLC pass candidates are not available in target groups..."}

It would not therefore be surprising if social elites who are better educated and hold higher authority capture the benefits intended for the poor and vulnerable groups. Echoing these problems, respondents suggested:

"People with interest should be selected, trained, and deputed to their villages for service."

"Appropriate person has to be selected after doing needs assessment."

"Only those who are likely to go back and work actively in villages should be selected."

"Selection of the participants should be done after a baseline study of the whole district, and training should be provided to those where livestock service is not available."

"Natabad (fatalism) [in trainees' selection] should be completely gone."

These findings were consistent with Neopane (2007), who advised selecting trainees from areas where there were inadequate number of VAHWs serving the farmers.

Training and educational materials are crucial in any training, including vocational and hands-on training (e.g., VAHW training), where trainees are supposed to practice and/or simulate as much as possible to be competent to serve their intended clients. As stated in the following statements, RLSTCs lacked these facilities.

"Limited animals for practical. There is not any provision to conduct forage production classes at training center."

"There should be appropriate...training materials available."

"There is a shortage of training materials..."

"Poor management of educational materials." 
Dorms at training centers serve many purposes. Trainees spend most of their off-training time in dorms, and the dorm facilities. Trainees' engagement at the dorms greatly affect their learning. They can perform their assignments and carry out their project works in the dorm. Respondents indicated that there were no dorms at some training centers, and some dorms did not have eateries where trainees could get foods and snacks.

Respondents felt training participants were not given adequate daily subsistence allowance (DSA). Demand for privatization of veterinary services, and collaboration and partnership among private and public education and training providers are in the rise. Providing training for free and paying a daily allowance to the participant should not be an issue. Instead there are poor and vulnerable people who need and deserve this training more than others. If attendees are unable to participate in the training because of his/her lack of affordability, such participants should be provided with a DSA.

The respondents expressed the need for refresher training for both VAHWs and RLTSCs employees, and monitoring and evaluation (M \& E) of the training program, both of which are critical post-training issues for program effectiveness. Agricultural and animal health technologies are evolving as are new livestock diseases and crop pests. VAHWs need updated information and new skill sets to address these emerging issues. Therefore, the call for refresher training is timely and urgently warranted. Similarly, frequent evaluation of the program improves program efficiency as problems will be brought to the notice of stakeholders more frequently, prompting the authority to act in a more timely manner (Rogers, 2003; Saks \& Burke, 2012). In developing countries like Nepal where program planning is generally a top-down approach, field inputs collected from frequent evaluation will be important to reverse this trend.

Lack of a legal base for VAHW services that respondents raised is a very pertinent issue hindering the services, which is consistent with the findings of Catley et al. (2004). When this training first started 40 years ago, legality of the services was not an issue. Getting services to farmers in rural areas, in whatsoever form they could be, was the sole goal then. Things have changed now, and the certification of any expertise must fulfill its legal obligations to its stakeholders. The Office International des Epizooties or World Organization for Animal Health (OIE), a governing body on world animal health services, mandates its member countries, of which Nepal is a signatory, to follow animal health protocols included in its charters, and to maintain the specified service standard (OIE, 2014).

\section{Conclusions and Recommendations}

Training center staff appreciated the VAHW training and they enumerated an exhaustive list of the problems and suggestions spanning a complete training cycle. Human resource management appeared to be an issue in need of attention in RLSTCs. First, there should be an adequate number of female staff in training centers. All employees should get orientation on gender integration on training program so that they do not discriminate anybody based on gender. Second, TOT should be prerequisite for the staff to serve in the RLSTCs. Staffs must get training on training management, subject-specific technologies, pedagogies, and information and communication technologies such as computer use and making presentations using Microsoft PowerPoint. This will help improve staffs' competencies as trainers, thus effective training. Third, frequent employee turnover necessitates additional resources to train new employees, negatively impacting sustainability of the training programs. DLS may create a new employee category, specifically for training resource personnel and employees.

Management of training materials remained problematic. Participants and instructors should have access to the required materials that they need to participate and facilitate training programs. Similarly, the need for monitoring and evaluation and refresher training has been recognized. Harmonizing VAHW services per national veterinary services, for example, legalizing and quality control of the VAHW services are the pressing issues requiring immediate attention.

Flexibility in educational qualifications of participants from remote and rural locations is a necessity. Training centers can provide a pre-training orientation for participants if needed to qualify them for such training. Involving local communities in training needs assessment, trainee selection, follow-up of training, and transfer of training programs is essential. This involvement will help select appropriate participants for training, improve community ownership of the VAHW program and its outcomes, and ultimately help sustain VAHW program. Training providers and sponsors are advised to consider local needs of the animal health services, candidate' backgrounds, and their willingness to work with livestock entrepreneurs and in livestock sector while selecting training participants.

To conclude, the study showed that staff are very important and essential part of an organization including education and training organization. Soliciting their input about training and training participants is important to better understand strategies and methods to conduct training programs effectively.

\section{Acknowledgements}

The author would like to thank Regional Livestock Services Training Center employees in Nepal who volunteered to take part in this study. This study greatly benefited from the support provided by the director of the Directorate of Livestock Training Services, which was truly appreciable. The author greatly appreciated the funding and advisory support provided by the Department of Community Sustainability and Dr. Murari Suvedi at Michigan State University. The author is grateful to anonymous reviewers who reviewed the manuscript and provided invaluable comments.

\section{References}

Allport, R., Mosha, R., Bahari, M., Swai, E., \& Catley, A. (2005). The use of community-based animal health workers to strengthen disease surveillance systems in Tanzania. Revue Scientifique et Technique-Office International des Epizooties, 24(3), 921.

Banta, T. W., \& Kuh, G. D. (1998). A missing link in assessment: Collaboration between academic and student affairs professionals. Change: The Magazine of Higher Learning, 30, 40-46.

Blatchford, P., Bassett, P., Brown, P., Martin, C., Russell, A., \& Webster, R. (2009). Research brief: Deployment and impact of support staff project. 
DCSF-RB148 (August 2009) ISBN 978184775515 5. London, UK: Department for Children, School and Families, University of London.

Bourque, L. B., \& Fielder, E. (2003). How to conduct self-adminstered and mail surveys $\left(2^{\text {nd }} E d\right)$. SAGE Publications.

Calba, C., Ponsich, A., Nam, S., Collineau, L., Min, S., Thonnat, J., \& Goutard, F. L. (2014). Development of a participatory tool for the evaluation of village animal health workers in Cambodia. Acta Tropica, 134, 17-28.

Catley, A., Leyland, T., Mariner, J. C., Akabwai, D. M. O., Admassu, B. Asfaw, W., \& Hassan, H. S. (2004). Para-veterinary professionals and the development of quality, self-sustaining community-based services. Revue Scientifique et Technique-Office International des Epizooties, 23(1), 225252.

Cho, K. M., \& Boland, H. (2004). Agricultural training in Myanmar: Extension agents' perceptions of training needs. Journal of International Agriculture and Extension Education, 11, 5-15.

Das, P., \& Mishra, P. (2013). An Assessment of application of learning of the training programs conducted by Extension Education Institute, Jorhat, Assam. Journal of Academia and Industrial Research (JAIR), 2(2), 80.

DLS (2011). Annual progress report (2009/2010). Department of Livestock Services, Nepal.

FAO (2019). Country gender assessment of agriculture and the rural sector in Nepal. Kathmandu.76 pp. License: CC BY-NC-SA 3.0 IGO.

Ghimire, R. P., \& Suvedi, M. (2013). Village animal health worker training in Nepal: A follow-up study [Abstract]. Journal of International Agricultural and Extension Education, 20(2).

IRIN (2013). Analysis: Why livestock matters in Nepal. Integrated Regional Information Network (IRIN).

http://www.irinnews.org/report/98463/analysis-why-livestock-matters-innepal.

Khanh, T. T., Ha, N. V., Phengsavanh, P., Horne, P., \& Stür, W. (2006). The contribution of livestock systems to livelihood sustainability in the central highlands of Vietnam. In Proceedings, Towards Sustainable Livelihoods and Ecosystems in Mountainous Regions. Chiang Mai, Thailand, March 79, 2006,

https://www.researchgate.net/profile/Phonepaseuth_Phengsavanh/publicati on/266042990_The_contribution_of_livestock_systems_to_livelihood_sus tainability_in_the_central_highlands_of_Vietnam/links/54b79f8f0cf2e $68 \mathrm{e}$ b28032d4.pdf.

Kshatri, B. B. (2011). Final evaluation report. Animal Health Training and Consultancy Services, Nepal.

Lim, D. H., \& Johnson, S. D. (2002). Trainee perceptions of factors that influence learning transfer. International Journal of Training and Development, 6(1), 36-48.

Meijerink, J. G., Bondarouk, T., \& Lepak, D. P. (2016). Employees as active consumers of HRM: Linking employees' HRM competences with their perceptions of HRM service value. Human Resource Management, 55(2), 219-240

Mitchell, C., \& Sackney, L. (2007). Extending the learning community: A broader perspective embedded in policy. In: L. Stoll, L., \& K.S. Louis (Eds.) Professonal Learning Communities: Divergence, Depth and Dilemma, Open University Press.
Mockshell, J., Ilukor, J., \& Birner, R. (2014). Providing animal health services to the poor in Northern Ghana: Rethinking the role of community animal health workers? Tropical Animal Health and Production, 46(2), 475-480.

Mugunieri, G. L., Irungu, P., \& Omiti, J. M. (2004). Performance of community-based animal health workers in the delivery of livestock health services. Tropical Animal Health and Production, 36(6), 523-535.

Neopane, S. R. (2007). Animal health project study report. Pokhara, Nepal: Animal Health Training and Consultancy Services, Nepal.

Nepal Veterinary Council (NVC). (2019). Registered veterinarians. Kathmandu, Nepal. http://www.nvc.com.np/council.php

OIE (2014). Objectives. World Organization for Animal Health (OIE). http://www.oie.int/about-us/our-missions/\#c202

Ojango, J. M. K., Malmfors, B., Mwai, O., \& Philipsson, J. (2011). Training the trainers--An innovative and successful model for capacity building in animal genetic resource utilization in Sub-Saharan Africa and Asia. ILRI and SLU.

Olivier, E. (2006). Job demands, job resources, burnout, health, and life satisfaction of support staff in a higher education institution. Master's Thesis. North-West University, Potchefstroom Campus, South Africa.

Pitman, T. (2000). Perceptions of academics and students as customers: A survey of administrative staff in higher education. Journal of Higher Education in Policy Manangement, 22(2).

Rapsomanikis, G. (2015). The economic lives of smallholder farmers: An analysis based on household data from nine countries. Rome, Food and Agriculture Organization of the United Nations. http://www.fao.org/3/ai5251e.pdf.

Riviere-Cinnamond, A. (2005.) Animal health policy and practice: Scaling-up community-based animal health systems, lessons from human health. Propoor Livestock Policy Initiative Working Paper 22. http://www.fao.org/ag/againfo/programmes/en/pplpi/docarc/wp22.pdf.

RLSTCs. (2011). Annual reports. Dhuabi/Janakpur/Pokhara/Nepalgunj/Dhangadhi, Regional Livestock Services Training Centers, Nepal [Nepali].

Rogers, E. M. (2003). Diffusion of innovations (5th edn.). New York, NY: Free Press.

Saks, A. M., \& Burke, L. A. (2012). An investigation into the relationship between training evaluation and the transfer of training. International Journal of Training Development, 16, 118-127.

Santos, A., \& Stuart, M. (2003). Employee perceptions and their influence on training effectiveness. Human Resource Management Journal, 13(1), $27-$ 45.

Stoufer, K., Ojha, N. D., \& Parajuli, A. (2002). Village animal health workers in Nepal: The pros and cons of developing a National Skills Test. PLA Notes, 45, 34-36. https://pubs.iied.org/pdfs/9218IIED.pdf

Umali, D L., Feder, G., \& Hann, C. D. (1994). Animal health services: Finding the balance between public and private delivery. The World Bank Research Observer [International], 9, 71-96. http://jstor.org/stable/3986550

Vella, J. (2002). Learning to listen - Learning to teach: The power of dialogue in educating adults. San Francisco, CA: Jossey-Bass.

Young, J., Stoufer, K., Ojha, N., \& Dijkema, H. P. (1994). Case study animal healthcare training: Nepal's animal health improvement training program. Warwickshire, UK: Practical Action Publishing. 